\title{
Carbon metabolism and nutrient balance in a hypereutrophic semi-intensive fishpond
}

\author{
Marcellin Rutegwa ${ }^{1, *}$, Jan Potužák ${ }^{1,2}$, Josef Hejzlar ${ }^{3}$ and Bořek Drozd ${ }^{1}$ \\ ${ }^{1}$ Institute of Aquaculture and Protection of Waters, South Bohemian Research Centre of Aquaculture and Biodiversity of Hydrocenoses, \\ Faculty of Fisheries and Protection of Waters, University of South Bohemia in České Budějovice, 37005 České Budějovice, \\ Czech Republic \\ 2 Institute of Botany of the Czech Academy of Sciences, Department of Vegetation Ecology, 60200 Brno, Czech Republic \\ ${ }^{3}$ Biology Centre of the Czech Academy of Sciences, Institute of Hydrobiology, 37005 České Budějovice, Czech Republic
}

Received 3 June 2019 / Accepted 29 October 2019

\begin{abstract}
Eutrophication and nutrient pollution is a serious problem in many fish aquaculture ponds, whose causes are often not well documented. The efficiency of using inputs for fish production in a hypereutrophic fishpond (Dehtář), was evaluated using organic carbon (OC), nitrogen (N) and phosphorus (P) balances and measurement of ecosystem metabolism rates in 2015. Primary production and feeds were the main inputs of OC and contributed $82 \%$ and $13 \%$ to the total OC input, respectively. Feeds and manure were the major inputs of nutrients and contributed $73 \%$ and $86 \%$ of the total inputs of $\mathrm{N}$ and $\mathrm{P}$, respectively. Ecosystem respiration, accumulation in water and accumulation in sediment were the main fates of OC, $\mathrm{N}$ and $\mathrm{P}$, respectively. They accounted for $79 \%, 52 \%$ and $61 \%$ of OC, $\mathrm{N}$ and $\mathrm{P}$ inputs. The efficiency of using $\mathrm{OC}, \mathrm{N}$ and $\mathrm{P}$ inputs to produce fish biomass was very low and represented $0.9 \%, 25 \%$ and $23 \%$ of total OC, $\mathrm{N}$, and $\mathrm{P}$ inputs, indicating an excessive phytoplankton production and overdosing of fish feeds and manure. Dehtár pond was slightly autotrophic and phosphorus availability did not limit the phytoplankton growth. The low efficiency of using inputs was attributed to the low digestibility of raw cereals grain used as feed and the inability of planktonic food webs to transfer the primary production to fish due to high predatory pressure of fish stock on zooplankton. The primary production is an important input of OC in semi-intensive fishponds and should be considered in evaluations of fish production efficiency.
\end{abstract}

Keywords: Aquaculture pond / input use efficiency / metabolism / organic carbon / nitrogen / phosphorus / primary production / freshwater fish production

Résumé - Métabolisme du carbone et équilibre des nutriments dans un étang eutrophe d'aquaculture semi-intensive. L'eutrophisation et la pollution par les nutriments constituent un grave problème dans de nombreux étangs piscicoles, dont les causes sont souvent mal documentées. L'efficacité de l'utilisation des intrants pour la production de poissons dans un étang hypertrophique (Dehtář) a été évaluée à l'aide des bilans du carbone organique (CO), de l'azote $(\mathrm{N})$ et du phosphore (P) et de la mesure des taux du métabolisme des écosystèmes en 2015. La production primaire et les aliments pour animaux étaient les principaux intrants de $\mathrm{CO}$ et contribuaient respectivement à $82 \%$ et $13 \%$ de l'intrant total en CO. Les aliments du bétail et le fumier étaient les principaux intrants d'éléments nutritifs et contribuaient à $73 \%$ et $86 \%$ des intrants totaux d'azote et de phosphore, respectivement. La respiration de l'écosystème, l'accumulation dans l'eau et l'accumulation dans les sédiments étaient les principaux devenirs du CO, du N et du $\mathrm{P}$, respectivement. Ils représentaient $79 \%, 52 \%$ et $61 \%$ des intrants du CO, de l'azote et du phosphore. L'efficacité de l'utilisation des intrants de $\mathrm{CO}, \mathrm{N}$ et $\mathrm{P}$ pour produire de la biomasse de poisson était très faible et représentait $0,9 \%, 25 \%$ et $23 \%$ des intrants totaux de $\mathrm{CO}, \mathrm{N}$ et $\mathrm{P}$, ce qui indique une production excessive de phytoplancton et un surdosage des aliments pour poissons et du fumier. L'étang Dehtár était légèrement autotrophe et la disponibilité du phosphore n'a pas limité la croissance du phytoplancton. La faible efficacité de l'utilisation des intrants a été attribuée à la faible digestibilité des céréales brutes utilisées comme aliments pour animaux et à l'incapacité des réseaux alimentaires planctoniques à transférer la production

\footnotetext{
*Corresponding author: mrutegwa@frov.jcu.cz
} 
primaire aux poissons en raison de la forte pression prédatrice des stocks de poissons sur le zooplancton. La production primaire est un intrant important du $\mathrm{CO}$ dans les étangs semi-intensifs et devrait être prise en compte dans les évaluations de l'efficacité de la production piscicole.

Mots-clés : Bassin aquacole / efficacité d'utilisation des intrants / métabolisme / carbone organique / azote / phosphore / production primaire / production de poissons d'eau douce

\section{Introduction}

Fish production in semi-intensive aquaculture depends, in addition to the natural productivity of ponds, on manuring and supplementary feeding (Broyer and Curtet, 2012; Wezel et al., 2013). Manure is added in fishponds in order to increase fish yields by supporting primary production and feed is added to sustain high density of fish stock that can no longer rely on the food produced naturally in the fishpond (Adámek, 2014; KnudHansen et al., 1991). The efficiency of using inputs in semiintensive fishpond management depends on the flow of energy in the food chain towards fish, either through the grazing or the detritus food chains (Pokorný et al., 2005). The availability of abundant zooplankton and macroinvertebrates throughout the growing season plays a key role in maintaining this efficiency in carp ponds. However, the intensification of fish production, together with inputs of nutrients and organic residues from wastewater and agricultural areas, has often resulted in fishpond eutrophication (Nhan et al., 2006; Pokorný and Hauser, 2002). In summer months, hypereutrophic water bodies (Vollenweider and Kerekes, 1982) are characterised by a primary producer community dominated by planktonic cyanobacteria and a low biomass of zooplankton (Pálffy et al., 2013; Scheffer et al., 2001; Sommer et al., 2012). Increased turbidity and availability of nutrients favour the growth of cyanobacteria while fish grazing pressure and lack of edible phytoplankton limit the growth of zooplankton. Fish in hypereutrophic ponds and lakes are threatened by phytoplankton die off followed by drops in dissolved oxygen levels that can even reach lethal values for fish (Jeppesen et al., 1990; Schindler et al., 2008). Such states indicate that the planktonic primary production of the pond exceeds the capacity of the food chain to exploit the produced phytoplankton biomass (Pechar, 2000; Potužák et al., 2007). In addition, the hypereutrophic condition of water bodies is a sign that the system receives nutrients in excess, especially phosphorus, which is considered a limiting factor for the primary production in freshwater ecosystems (Reynolds and Davies, 2001; Schindler et al., 2008).

Improvement of pond water quality and pond effluent is crucial to achieve an ecological sustainable aquaculture (Alongi et al., 2009). A balance between the amount of supplemented nutrients and organic matter added and that used to produce fish biomass is required to avoid excessive fishpond eutrophication (Bosma and Verdegem, 2011). Prior to taking actions to try to improve the water quality in fishponds, it is important to understand the sources, sinks and transformation of nutrients and organic matter in fishponds. The magnitude of total primary production and respiratory processes in the aquatic ecosystem and the use of nutrients can be determined by measuring diurnal changes in dissolved oxygen (DO) concentrations and nutrient balance (Adhikari et al., 2012;
Staehr et al., 2010). Using these methods, it is also possible to show how effective the fertilization and application of fish feed is for the growth and the production of fish in ponds.

The aim of this study was to assess the effective utilisation of organic carbon (OC) and nutrient inputs for the production of fish in the Dehtár pond, a typical representative of semiintensive, hypereutrophic fishponds in the Czech Republic (Pechar, 2000). Specific objectives were to determine ecosystem metabolic rates, carbon and nutrient balance and to compare the inputs to the amount of nutrients that were really needed to attain the produced fish biomass. In addition, phosphorus regeneration in the fishpond and the amount of phosphorus needed to counterbalance its limitation in the system were also measured. We hypothesise that the inefficient use of nutrients, mainly P, its overdosing and then its re-cycling within the aquatic ecosystem lead to hypereutrophic conditions observed in semi-intensive fishponds.

\section{Methodology}

\subsection{Study area}

The Dehtář pond (49.0083N, 14.3058E; 406.4 m above sea level) is situated in the upper Vltava River basin and is the last and lowest water body in the system of fishponds in the upper basin of the Dehtářský stream (Fig. 1). It ranks among the ten largest Czech fishponds, having a surface area of $2.28 \mathrm{~km}^{2}$, maximum and mean depths of 5.5 and $2.2 \mathrm{~m}$, respectively, and a catchment area of $91.4 \mathrm{~km}^{2}$ (Potužák et al., 2016). It is used as a polyculture semi-intensive fishpond. Manure and supplementary feed, mainly wheat, rye or barley grains, are added to increase fish production over natural productivity, which is between ca 100 and $200 \mathrm{~kg} \mathrm{ha}^{-1} \mathrm{yr}^{-1}$ in this region (Kestemont, 1995; Pechar, 2000). Common carp (Cyprinus carpio L.) usually represents $95 \%$ of stocked fish biomass and the remaining $5 \%$ are composed of grass carp (Ctenopharyngodon idella Valenciennes 1844), bighead carp (Hypophthalmichthys nobilis Richardson 1845), pike-perch (Sander lucioperca L.), and northern pike (Esox lucius L.). It is one of the fishponds called main ponds as it is stocked with two-yearold carp that are harvested at the end of a two-year growing cycle. Ponds in which younger fish are kept are known as nursery ponds (Pokorný and Pechar, 2000). This study was carried out during the first year of the fish production cycle.

\subsection{Sampling and data used}

Three platforms equipped with high frequency stations for recording water temperature $\left(T_{w}\right)$ and dissolved oxygen (DO) (M4016, Fiedler AMS) were installed in the Dehtár pond at three sites (Fig. 1), i.e. at the dam (D), Dehtářský bay (DB), and Babický bay (BB). $T_{w}$ and DO were recorded in 10 minute 


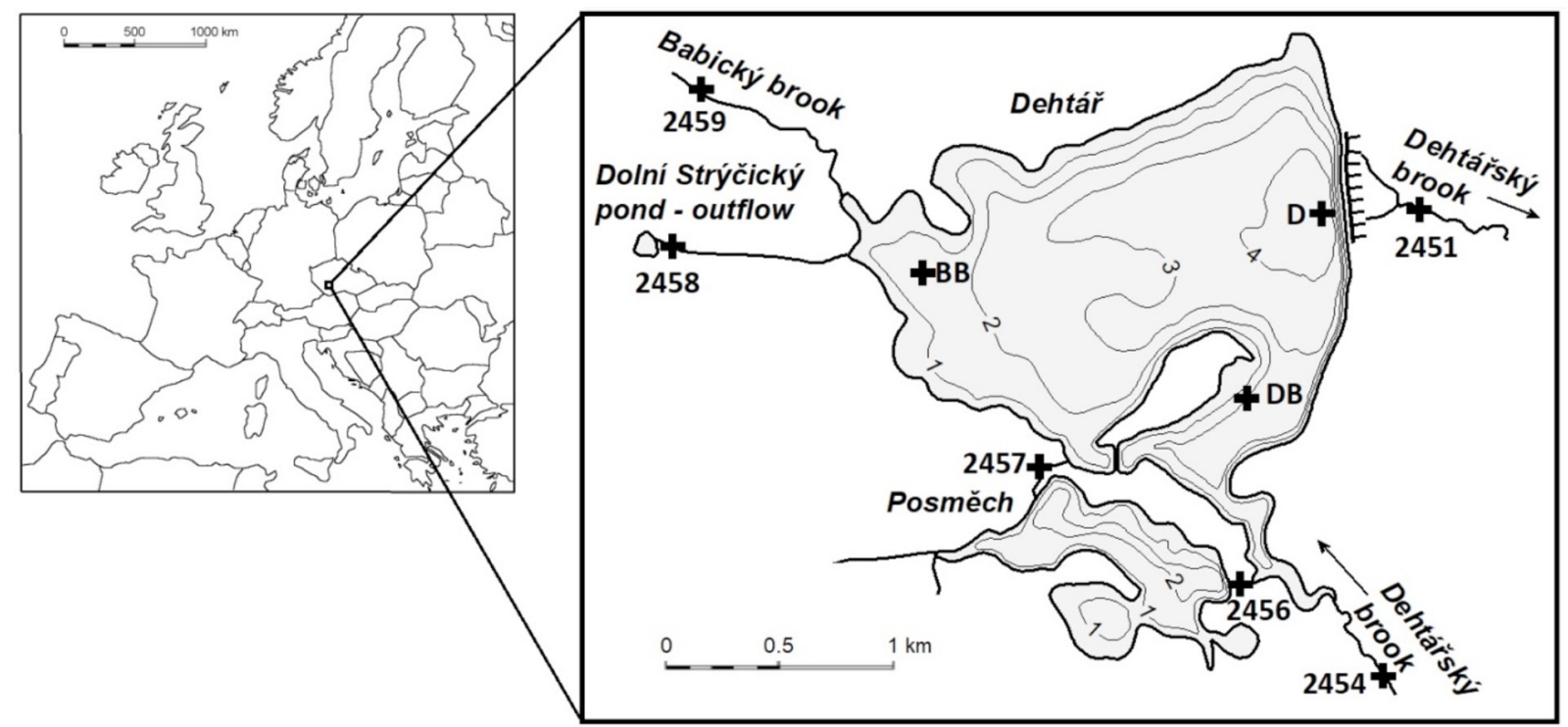

Fig. 1. Location of the Dehtár pond. The crosses indicate the metabolism measurements and water sampling sites. The isobaths in the Dehtář and Posměch ponds show the depths in meters at the water level at maximum filling.

intervals at $0.3-\mathrm{m}$ and $1.5-\mathrm{m}$ depths at the dam (site D) and at $0.3-\mathrm{m}$ depth at sites $\mathrm{DB}$ and $\mathrm{BB}$. Site $\mathrm{D}$ was also equipped with a meteorological station (M4016-A-G3, Fiedler AMS) to record air temperature, wind speed at 2-m height, and shortwave incident radiation at the same intervals as above. The stations were operated from April to November 2015. Maintenance, checking and re-calibration of the stations were performed at weekly or two-week intervals based on algal growth on the sensors.

For the evaluation of water quality and nutrient balance, water samples were taken from the pond, its tributaries, and the outflow. On days of the maintenance of stations, integrated water samples were taken from the top 2-m layer at all three sites and grab samples from the $3-\mathrm{m}$ depth and $0.5 \mathrm{~m}$ above the bottom at site D using a Friedinger sampler. All five tributaries (i.e., sites No. 2454, 2456, 2457, 2458, 2459; Fig. 1) and the outflow (No. 2451; Fig. 1) were sampled and their flow was measured once a month from December 2014 to March 2015, and every two weeks from April to November 2015. The samples were analysed for concentrations of nutrients, namely total carbon (TC), total organic carbon (TOC), dissolved organic carbon (DOC), particulate organic carbon (POC), total nitrogen (TN), nitrate nitrogen $\left(\mathrm{N}^{-\mathrm{NO}_{3}}{ }^{-}\right)$, ammonium nitrogen $\left(\mathrm{N}^{-\mathrm{NH}_{4}}{ }^{+}\right)$, total phosphorus (TP), dissolved phosphorus (DP), soluble reactive phosphorus (SRP), and chlorophyll $a(\mathrm{Chl} a)$. The analyses are specified in Supplementary Material, Table S1. The flow was measured using a hydrometric probe (FlowTracker, Sontek, USA). In the pond at sites D, DB and BB, water transparency was measured with a Secchi disc and a multiparametric probe (YSI $6600 \mathrm{~V} 2-4)$ was used to record vertical profiles of $T_{w}$ and DO at $0.5 \mathrm{~m}$ depth intervals. Water level in the pond was read out at a gauge fixed at the dam structure weekly or more frequently from January to December 2015.

The hydrological characteristics of the Dehtár pond, namely its inflows, outflows, volume of stored water and water level changes, were reconstructed in a daily time step. First, the two-weekly measured data in the inflows were completed by the hydrological analogy from the recorded daily flow data in a nearby stream (the Zlatý potok) and information on the timing of filling up and/or emptying of the ponds situated upstream in the catchment. Then the water balance of the Dehtár pond was calculated as the difference between water inputs (the reconstructed daily inflows plus daily precipitation on the pond surface) and losses of water (evaporation, outflow and seepage). The loss of water by seepage was calculated by subtracting the inputs from the other losses and was positively correlated with the level of pond filling. The precipitation data originated from the climatic station of the Czech Hydrometeorological Institute at České Budějovice $(48.9518 \mathrm{~N}$, 14.4698E; distance from the Dehtář pond ca $13 \mathrm{~km}$ ). Daily evaporation from the pond was calculated using the PenmanMontheith formula based on daily average temperature, air humidity, radiation and wind speed data (Wetzel, 2001). The theoretical water residence time was calculated by dividing the average water volume of the Dehtár pond by the average inflow (George and Hurley, 2003).

\subsection{Metabolism measurements, phosphorus regeneration and phosphorus demand}

Ecosystem metabolic rates in the pond were calculated using a model developed for lakes (Hanson et al., 2003; Staehr et al., 2010) expressed in the equation: $\Delta \mathrm{O}_{2} / \Delta t=$ GPP-ER-F-A. In this formula, $\Delta \mathrm{O}_{2} / \Delta t$ is the change in dissolved oxygen over time, GPP the gross primary production, ER the total ecosystem respiration, $F$ the oxygen exchange with the atmosphere, and A includes other processes affecting the concentration of dissolved oxygen such as inflow, outflow, leakage or photochemical decomposition of humic substances. $\Delta \mathrm{O}_{2} / \Delta t$ was determined from measured dissolved oxygen concentrations that were area and volume weighted at each of the three sites. The $F$ values were modelled as a function of the concentration gradient between the actual and 
saturation values of dissolved oxygen concentration at a given temperature and the coefficient of wind and temperature dependent reaction according to Staehr et al. (2010). The values of A were neglected as insignificant for the conditions present at the Dehtár pond (Coloso et al., 2011; Staehr et al., 2010). Since the primary production is zero at night, the ecosystem respiration was calculated from the decrease of dissolved oxygen in the pond during the night and from exchange with the atmosphere (Lauster et al., 2006; Sadro et al., 2011). Furthermore, assuming that ecosystem respiration is the same during the day and night, the hourly average respiration was multiplied by 24 hours to obtain total daily ecosystem respiration (ER). Daily net ecosystem production (NEP) was obtained by summing the change in oxygen concentration from all time steps from dawn to dawn. Gross primary production (GPP) was obtained by summing daily NEP and daily ER.

Regeneration and demand of orthophosphate phosphorus by the planktonic community were calculated from the monthly metabolic rates (Kamarainen et al., 2009; Knoll et al., 2016). First, the values of the GPP, ER and NEP were converted from oxygen units $\left(\mathrm{mg} \mathrm{m}^{-2} \mathrm{~d}^{-1} \mathrm{O}_{2}\right)$ to carbon units $\left(\mathrm{mg} \mathrm{m}^{-2} \mathrm{~d}^{-1} \mathrm{C}\right)$ multiplying them by 0.33 (i.e., mass ratio of $\mathrm{O}_{2}$ and $\mathrm{C}$ assuming a photosynthetic quotient of 1.15 (Knoll et al., 2016). Then, the net planktonic production (NPP) was calculated as the difference between GPP and autotrophic respiration ( $\left.R_{\text {auto }}\right)$, where $R_{\text {auto }}$ was assumed to be $70 \%$ of ER according to previous studies in eutrophic lakes (Biddanda et al., 2001; del Giorgio and Peters, 1993; Staehr et al., 2010). Heterotrophic respiration ( $R_{\text {hetero }}$ ) was assumed to be $30 \%$ of ER according to the same studies. Phosphorus regeneration was then obtained by dividing $R_{\text {hetero }}$ by seston $\mathrm{C} / \mathrm{P}$ ratio and phosphorus demand was obtained by dividing the NPP by seston C/P ratio (Kamarainen et al., 2009; Knoll et al., 2016).

\subsection{Balance of organic carbon and nutrients}

The balance of organic carbon, nitrogen and phosphorus in the Dehtár pond was calculated from May to October 2015 using the equation: $\Delta M / \Delta t=\mathrm{GPP}+\mathrm{IN}+\mathrm{AD}+\mathrm{FF}+\mathrm{M}-$ ER - OUT - FISH - RET. In this equation, $\Delta M / \Delta t$ is the change in the quantity of organic carbon or nutrients in the pond water between the beginning and the end of the balance period, GPP is the gross primary production (applicable for organic carbon only), IN, AD, FF, and $\mathrm{M}$ are the inputs from inflows, atmospheric deposition, fish feed, and manure, respectively, ER is the loss of organic carbon by ecosystem respiration, OUT and FISH are the outputs from the system by outflow plus seepage and by the uptake into the produced fish biomass, respectively, and RET is the calculated residual of the balance and represents retention in the sediment and/or loss to the atmosphere. The inputs by the inflows and atmospheric deposition and the outputs by the outflow and seepage were calculated for each month as the product of the monthly averaged measured concentrations and the corresponding monthly volumes of water entering or leaving the pond. Afterwards the monthly values were summed over the study period. The concentrations in the atmospheric deposition used were from the measurements of bulk precipitation at the Slapy reservoir. It is a long term project monitoring atmospheric

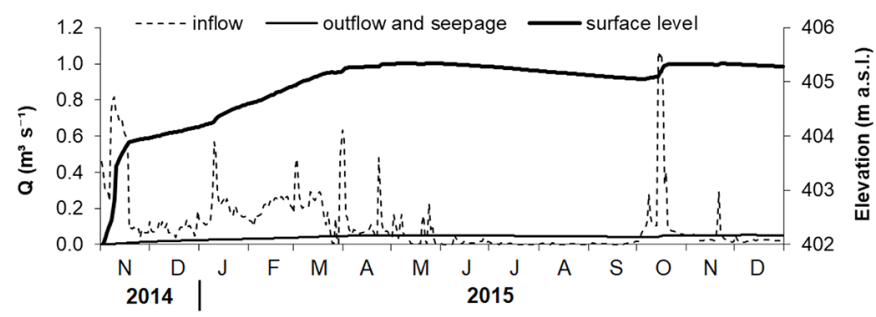

Fig. 2. Water inflow, outflow and losses by seepage, and trend of surface water level in the Dehtár pond during the period from November 2014 to December 2015.

deposition carried out by researchers from the Institute of Hydrobiology (Biology Centre of the Czech Academy of Sciences) (Kopáček et al., 1997). The volume-weighted means in the atmospheric deposition collected from May to October 2015 and used in the balance were $3.1 \mathrm{mg} \mathrm{l}^{-1}, 1.34 \mathrm{mg} \mathrm{l}^{-1}$ and $42 \mu \mathrm{g}^{-1}$ for TOC, TN and TP, respectively, and the depth of precipitation was $307 \mathrm{~mm}$ over the same period. The concentrations of TOC, TN and TP in manure, feed and fish were obtained from the literature. The TOC, TN and TP inputs in manure, feed and output in harvested fish were estimated by multiplying their quantity with their respective concentrations. The mean concentrations of TOC, TN and TP in manure (cattle straw manure) were $100,5.0$ and $1.3 \mathrm{~g} \mathrm{~kg}^{-1}$ (MA-CR, 1998) whereas those for the feed (wheat grain) were 420, 15 and $4.0 \mathrm{~g} \mathrm{~kg}^{-1}$ (Čermák et al., 2008; Hlaváč et al., 2015; Rachon et al., 2015), respectively. Concentrations of TOC, TN and TP in fish biomass were considered to be 150,40 and 7 to $9 \mathrm{~g} \mathrm{~kg}^{-1}$ (specifically for each species), respectively (Rothschein, 1983). The fish growth was estimated by empirical growth models for each species based on their stocked size and weight, and considering mortality losses that were calibrated for the Dehtár pond on six previous 2-year production periods with available data for stocking and harvest.

\section{Results}

\subsection{Fishpond management}

The Dehtár̆ pond started refilling just after autumn fish harvest in November 2014 but the surface level did not reach the level planned for the $1^{\text {st }}$ year of the production cycle (i.e., $405.85 \mathrm{~m}$ a.s.1.) due to dry weather conditions and little inflow (Fig. 2). The average pond morphological parameters during the balance period May-October 2015 were significantly smaller than its nominal values (i.e., volume $2.56 \mathrm{hm}^{3}$, flooded area $1.57 \mathrm{~km}^{2}$; maximum and mean depths 4.7 and $1.6 \mathrm{~m}$, respectively). The water renewal in the pond was minimal during the May-October period, with a theoretical water residence time of 1.6 years. The outflow from the pond occurred only through seepage, except at the end of October when a small amount of water was discharged through the main pond outlet at the dam.

Fish were stocked in November 2014 and in March 2015 ( $20 \%$ and $80 \%$ of the stocked biomass, respectively). The total biomass of the stocked fish was $390 \mathrm{~kg} \mathrm{ha}^{-1}$ and consisted of $97 \%$ of common carp, $2.3 \%$ of grass carp, $0.6 \%$ of pikeperch, $0.1 \%$ of pike, and $0.1 \%$ of bighead carp. The body weight of the stocked common carp was $360 \mathrm{~g}$ on average and increased 
(a)

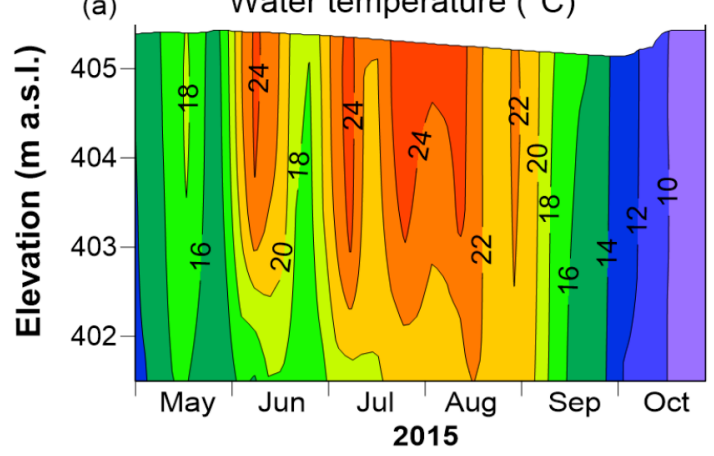

(b) Dissolved oxygen $\left(\mathrm{mg} \mathrm{l}^{-1}\right)$

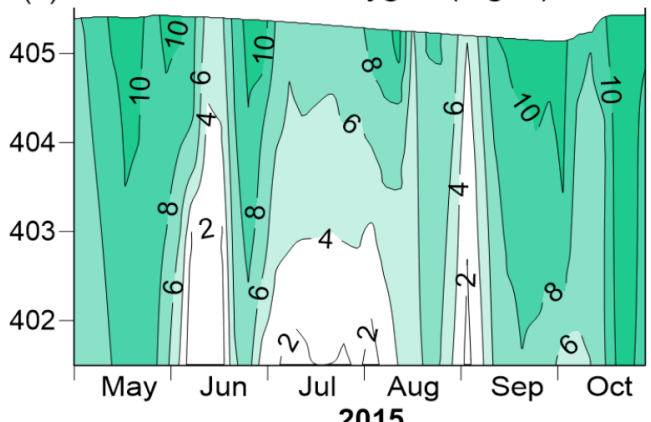

Fig. 3. Stratification of (a) water temperature $\left({ }^{\circ} \mathrm{C}\right)$ and (b) dissolved oxygen $\left(\mathrm{mg} \mathrm{l}^{-1}\right)$ in the Dehtár pond at site $\mathrm{D}$ during the period from May to October 2015 plotted using weekly or two-weekly measured profiles.

to ca $1.1 \mathrm{~kg}$ at the end of the growing season, according to our fish growth model. As in many Czech fishponds, also weed fish, dominated mainly by topmouth gudgeon (Pseudorasbora parva Temminck \& Schlegel, 1846) and including roach (Rutilus rutilus L.), common bream (Abramis brama L.), silver bream (Abramis bjoerkna L.), rudd (Scardinius erythrophthalmus L.), and Prussian carp (Carassius gibelio Bloch, 1782) (Musil et al., 2007), were present in the Dehtár pond. Their biomass and time of pond invasion were not recorded in this study but were noticed later, at the fish harvest in 2016 (J. Potužák, pers. commun.). The biomass of stocked fish nearly doubled by the end of the study period, when it was $750 \mathrm{~kg} \mathrm{ha}^{-1}$, according to the fish growth model. Cattle manure was used in the pond at the beginning of the growing season from March to April in the amount of $2200 \mathrm{~kg} \mathrm{ha}^{-1}$. Wheat grain was used as supplementary feed with 4, 13, 26, 37 and $20 \%$ of total feed applied in May, June, July, August and September, respectively. The amounts of fish feed took into account water temperature, visually assessed zooplankton biomass and increasing biomass of fish stock. Fish were fed twice a week in May and three times a week in the remaining months. The total amount of supplementary feed used over the study period was $1900 \mathrm{~kg} \mathrm{ha}^{-1}$. The food conversion ratio (FCR) that was calculated by dividing the feed amount (kg) by the live weight gain $(\mathrm{kg})$ of the fish was 5.7.

\subsection{Stratification and water quality}

Thermal and oxygen stratification in the water column at site D during May-October 2015 showed a general polymictic pattern (Fig. 3). Nevertheless, during periods of warm and still weather, the water column stratified and DO rapidly exhausted above the bottom, leading to hypoxia. Largely depleted DO in such temporarily formed hypolimnion was measured in the first half of June, during almost the whole of July until early August, and in the beginning of September. In late summer and autumn, stratification became unstable with frequent mixing of the entire water column. Nevertheless, a temporary mild stratification was observed in September and early October, when differences in $T w$ in the water column were low (usually $<0.5^{\circ} \mathrm{C}$ ) but DO concentrations at the surface and above the bottom differed significantly from the middle layers of the water column.
Dissolved and particulate fractions of $\mathrm{OC}, \mathrm{N}$ and $\mathrm{P}$ concentrations increased gradually in the Dehtár pond during the May-October period (Fig. 4b, e, h). The DOC and POC concentrations increased approximately twofold: DOC from about 11 to $20 \mathrm{mg} \mathrm{l}^{-1}$ and POC from about 4 to $9 \mathrm{mg} \mathrm{l}^{-1}$. Inorganic carbon (TIC) increased relatively less from about 21 to $30 \mathrm{mg}^{-1}$. A similar seasonal pattern of $\mathrm{C}$ concentrations also occurred in the inflow into the pond (Fig. 4a), but its effect on concentrations in the Dehtár pond was minimal due to a very low flow during the summer (Fig. 2). Phytoplankton was present in the pond at a high concentration all year, with a drop in spring and then a gradual increase during the growing season, as evidenced by an increase in Chla concentration from approximately $30 \mu \mathrm{g} \mathrm{l}^{-1}$ in spring to more than $100 \mu \mathrm{g} \mathrm{l}^{-1}$ at the end of summer (Fig. 4c) and from the transparency of water decreasing from $0.65 \mathrm{~m}$ in May to $0.4 \mathrm{~m}$ in summer (Fig. 4f). $\mathrm{TN}$ concentration in the pond gradually increased from ca 1 to $2.5 \mathrm{mg}^{-1}$ concurrent with an accumulation of organic $\mathrm{N}$ $(\mathrm{ON})$, while inorganic forms of nitrogen $\left(\mathrm{N}^{-\mathrm{NO}_{3}}{ }^{-}\right.$and $\left.\mathrm{N}-\mathrm{NH}_{4}{ }^{+}\right)$were low during the whole season $(<0.05 \mathrm{mg}$ $\left.1^{-1}\right)$. TP concentration also increased throughout the growing season to nearly $200 \mu \mathrm{g} \mathrm{l}^{-1}$ in the later summer and autumn, while SRP was relatively low $\left(10-40 \mu g 1^{-1}\right)$. Despite low concentrations of inorganic $\mathrm{N}$ and $\mathrm{P}$ forms, biomass of seston increased during the whole growing season with a sestonic molar C/P ratio ranging from 100 to 150 (Fig. 4i).

\subsection{Metabolic rates and phosphorus regeneration}

High-frequency measurement of the DO concentration at depths of 0.3 to $1.5 \mathrm{~m}$ showed large fluctuations of their daily values from hypersaturation to deeply hypoxic values (Fig. 5a). The DO concentrations in these layers were always higher than the critical survival concentration of about $2 \mathrm{mg} \mathrm{l}^{-1}$ for cyprinid fish (Svobodova et al., 1993). The metabolic rates showed very dynamic changes characterized by frequent alternations between periods of autotrophy and periods of heterotrophy (Fig. 5b, c). The number of autotrophic days (NEP $>0$ ) was almost equal to the number of heterotrophic days $(\mathrm{NEP}<0)$ with a proportion of $53 \%$ and $47 \%$, respectively. Daily rates of NEP ranged between -6.8 and $7.8 \mathrm{~g} \mathrm{O}_{2} \mathrm{~m}^{-2} \mathrm{~d}^{-1}$ with an average of $0.2 \mathrm{~g} \mathrm{O}_{2} \mathrm{~m}^{-2} \mathrm{~d}^{-1}$ (Fig. 5c) and the Dehtár pond was therefore slightly autotrophic. GPP 

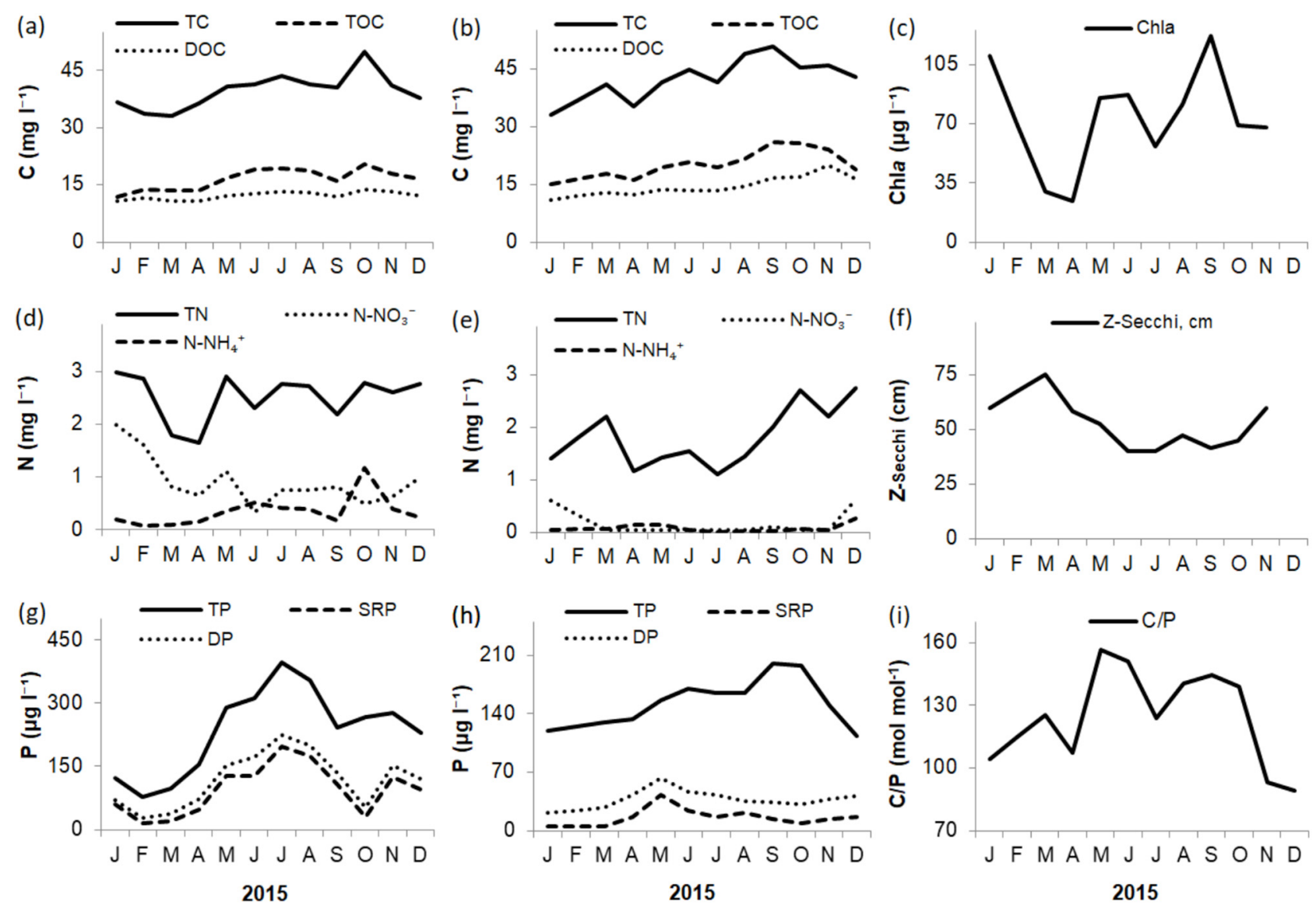

Fig. 4. Water quality in the Dehtár pond at site $\mathrm{D}$ and its inflow in 2015: (a) total carbon (TC), total organic carbon (TOC) and dissolved organic carbon (DOC) in the total volume-weighted inflow to the pond, (b) TC, TOC and DOC in the pond, (c) chlorophyll-a (Chla) in the pond, (d) total nitrogen (TN), nitrate nitrogen $\left(\mathrm{N}_{-} \mathrm{NO}_{3}{ }^{-}\right)$and ammonium nitrogen $\left(\mathrm{N}^{-\mathrm{NH}_{4}}{ }^{+}\right)$in the total volume-weighted inflow to the pond, (e) $\mathrm{TN}, \mathrm{N}-\mathrm{NO}_{3}-$ and $\mathrm{NH}_{4}{ }^{+}$in the pond, (f) water transparency (Z-Secchi), (g) total phosphorus (TP), dissolved phosphorus (DP) and soluble reactive phosphorus (SRP) in total volume-weighted inflow to the pond, (f) TP, DP and SRP in the pond, (i) C/P ratio in the pond.
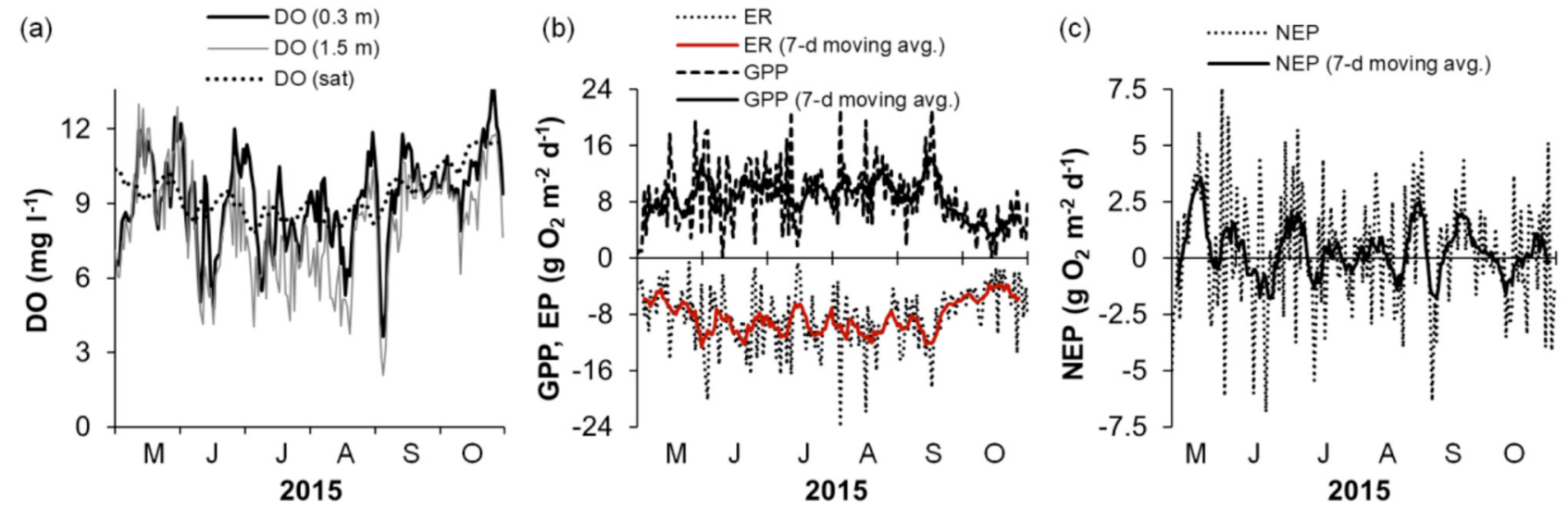

Fig. 5. Daily average values from May to October 2015 for: (a) dissolved oxygen concentrations at depths of 0.3 and $1.5 \mathrm{~m}$ and oxygen saturation concentration at the water surface; (b) gross primary production (GPP) and ecosystem respiration (ER); (d) net ecosystem production (NEP). 
Table 1. Monthly metabolic rates of $\mathrm{C}\left(\mathrm{g} \mathrm{m}^{-2} \mathrm{~d}^{-1}\right), \mathrm{C} / \mathrm{P}$ ratio of seston $\left(\mathrm{mol} \mathrm{mol}^{-1}\right), \mathrm{P}$ regeneration $\left(\mathrm{mg} \mathrm{m}^{-2} \mathrm{~d}^{-1}\right)$ and $\mathrm{P} \mathrm{demand}\left(\mathrm{mg} \mathrm{m}^{-2} \mathrm{~d}^{-1}\right)$ in the Dehtár pond water from May to October 2015.

\begin{tabular}{llllllll}
\hline & GPP & ER & NEP & NP & C/P & P regeneration & P demand \\
\hline May & 2.4 & 2.1 & 0.3 & 0.9 & 123 & 13 & 19 \\
June & 3.3 & 3.2 & 0.1 & 1.0 & 149 & 17 & 17 \\
July & 3.0 & 3.0 & 0.0 & 0.9 & 124 & 17 & 17 \\
August & 3.4 & 3.2 & 0.2 & 1.2 & 138 & 17 & 17 \\
September & 3.1 & 3.0 & 0.1 & 1.0 & 149 & 16 & 8 \\
October & 1.5 & 1.6 & -0.1 & 0.5 & 152 & 8 & 17 \\
Average & 2.8 & 2.7 & 0.1 & 0.9 & 139 & 15 & 17 \\
\hline
\end{tabular}

Table 2. Balance of OC, N and P in the Dehtář pond from May to October 2015 in metric tons and percentages related to total inputs.

\begin{tabular}{|c|c|c|c|c|c|c|}
\hline \multirow[t]{2}{*}{ Variable } & \multicolumn{2}{|c|}{ Organic carbon } & \multicolumn{2}{|c|}{ Nitrogen } & \multicolumn{2}{|c|}{ Phosphorus } \\
\hline & $(\mathrm{t})$ & $(\%)$ & $(\mathrm{t})$ & $(\%)$ & $(\mathrm{t})$ & $(\%)$ \\
\hline \multicolumn{7}{|c|}{ Inputs } \\
\hline GPP & 836 & 82 & - & - & - & - \\
\hline Inflow water & 18 & 1.7 & 2.48 & 27 & 0.27 & 13 \\
\hline Rainfall & 2.6 & 0.3 & 0.01 & 0.1 & 0.01 & 0.5 \\
\hline Feed & 133 & 13 & 4.75 & 53 & 1.27 & 63 \\
\hline Manure & 36 & 3.5 & 1.8 & 20 & 0.47 & 23 \\
\hline Total inputs & 1025 & 100 & 9.04 & 100 & 2.02 & 100 \\
\hline \multicolumn{7}{|c|}{ Outputs } \\
\hline ER & 807 & 79 & - & - & - & - \\
\hline Outflow and seepage & 17 & 1.7 & 1.27 & 14 & 0.13 & 6 \\
\hline Fish production & 8.8 & 0.9 & 2.3 & 25 & 0.46 & 23 \\
\hline Total outputs & 833 & 81 & 3.57 & 40 & 0.59 & 29 \\
\hline Accumulation in water & 30 & 2.9 & 4.66 & 52 & 0.2 & 10 \\
\hline Retention and/or losses & 162 & 15.8 & 0.81 & 9 & 1.23 & 61 \\
\hline
\end{tabular}

rates varied between 0.1 and $21.1 \mathrm{~g} \mathrm{O}_{2} \mathrm{~m}^{-2} \mathrm{~d}^{-1}$ with an average of $8.5 \mathrm{~g} \mathrm{O}_{2} \mathrm{~m}^{-2} \mathrm{~d}^{-1}$ (Fig. 5b). ER rates varied between 0.4 and $24 \mathrm{~g} \mathrm{O}_{2} \mathrm{~m}^{-2} \mathrm{~d}^{-1}$ with an average of $8.2 \mathrm{~g} \mathrm{O}_{2}$ $\mathrm{m}^{-2} \mathrm{~d}^{-1}$ (Fig. 5b). Monthly averages values of GPP and ER were higher from June to September while NEP increased moderately in May and August (Tab. 1). The rate of $\mathrm{P}$ regeneration in the planktonic community was in the range of $8-19 \mathrm{mg} \mathrm{m}^{-2} \mathrm{~d}^{-1}$ while $P$ demand ranged between 8 and $22 \mathrm{mg} \mathrm{m}^{-2} \mathrm{~d}^{-1}$ (Tab. 1).

\subsection{Organic carbon and nutrient balance}

Total inputs of OC into the Dehtár pond during the 2015 growing season were $1025 \mathrm{t}$ (Tab. 2). GPP, fish feeds and manure were the pond's main sources with a contribution of 82,13 and $3.5 \%$ of all OC inputs, respectively. Manure was included in the balance because, although it was used before the beginning of the balance period, its decomposition is slow and its effect persists during the growing season. Ecosystem respiration was the main pathway of OC output from the system and accounted for $79 \%$ of all OC inputs. A small amount of OC (1.7\%) left the system through the outflow and seepage, and an even smaller fraction $(0.9 \%$ of OC inputs) was assimilated in the produced fish biomass. The fraction of OC that accumulated in the pond water, the calculated retention in the sediment, and/or loss of OC to the atmosphere represented 2.9 and $15.8 \%$ of all OC inputs, respectively.

Inputs of $\mathrm{N}$ and $\mathrm{P}$ into the Dehtár pond during the growing season of 2015 were $9.0 \mathrm{t}$ and $2.0 \mathrm{t}$, respectively (Tab. 2). The main source for both nutrients was aquaculture: feed and manure applications contributed $73 \%$ of $\mathrm{N}$ inputs and $86 \%$ of $\mathrm{P}$ inputs. Inflows were the second most important source of nutrients into the pond and contributed 27 and $13 \%$ to TN and TP inputs, respectively. Unlike OC, relatively higher percentages of nutrients inputs were incorporated in the biomass of produced fish, namely 25 and $23 \%$ for TN and TP, respectively. The outflow and seepage accounted for $14 \%$ of $\mathrm{TN}$ and $6 \%$ of TP inputs in the pond. A significant proportion of $\mathrm{N}$ accumulated in the pond water during the growing season (i.e., $52 \%$ of TN inputs), whereas only $9 \%$ of TN was retained in the sediment and/or lost from the system. In contrast, the accumulation of $\mathrm{P}$ in pond water and $\mathrm{P}$ retention were 10 and $61 \%$ of TP inputs, respectively, indicating that $\mathrm{P}$ is more susceptible to sedimentation than $\mathrm{N}$. 
Table 3. Example values of metabolic rates in some selected lakes. $Z_{\text {mean }}(\mathrm{m})$ : mean depth of the lake, GPP $\left(\mathrm{mmol} \mathrm{O}_{2} \mathrm{~m}^{-2} \mathrm{~d}^{-1}\right)$ : gross primary production, ER $\left(\mathrm{mmol} \mathrm{O}_{2} \mathrm{~m}^{-2} \mathrm{~d}^{-1}\right)$ : ecosystem respiration, NEP $\left(\mathrm{mmol} \mathrm{O}_{2} \mathrm{~m}^{-2} \mathrm{~d}^{-1}\right)$. International country codes based on the ISO 3166 standard published by the International Organization for Standardization (https://www.iso.org/iso-3166-country-codes.html) are in parentheses.

\begin{tabular}{|c|c|c|c|c|c|c|c|}
\hline Lake & $Z_{\text {mean }}$ & Trophic status & Major source of OC & GPP & ER & NEP & Reference \\
\hline Yuan-Yang (TWN) & 1.5 & Oligotrophic/dystrophic & Allochthonous & 0.03 & 0.09 & -0.06 & Tsai et al. (2008) \\
\hline Northgate Bog (USA) & 1.5 & Oligotrophic/dystrophic & Allochthonous & 11 & 116 & -105 & Hanson et al. (2003) \\
\hline Hummingbird (USA) & 1.5 & Mesotrophic/dystrophic & Allochthonous, phytoplankton & 23 & 219 & -196 & Hanson et al. (2003) \\
\hline Võrstjär (EST) & 2.8 & Eutrophic & Phytoplankton & 97 & 94 & 3 & Laas et al. (2012) \\
\hline Apopka (USA) & 1.7 & Hypereutrophic & Phytoplankton, sediment & 104 & 198 & -94 & Bachmann et al. (2000) \\
\hline Albardiosa (ESP) & 0.26 & Hypereutrophic & Macrophytes & 175 & 152 & 23 & Florín and Montes (1998) \\
\hline Dehtář (CZE) & 1.7 & Hypereutrophic & Phytoplankton & 265 & 257 & 8 & This study \\
\hline Santa Olalla (E & 0.37 & Hype & Phyt & 285 & 308 & -23 & López-Archill \\
\hline Frederiksborg Slotssø (DNK & 3.5 & Hypereutrophic & Phytoplankton & 366 & 357 & 9 & Staehr and Sand-Jensen (2007) \\
\hline
\end{tabular}

\section{Discussion}

\subsection{Structure of fishpond ecosystem, trophic conditions and metabolism}

The ecosystem structure of Dehtár pond reflected the effect of reared fish that were stocked at high density. The phytoplankton community were dominated by colonial, filamentous algae and cyanobacteria during the summer months (Fránková et al., 2017), submersed aquatic plants were absent whereas emergent macrophytes were sparse in the littoral zone (K. Sumberová et al., unpubl. data). The zooplankton community was composed mainly of small-sized zooplankton species (e.g. Bosmina longirostris, nauplii, cyclopoid copepods, rotifers) and macroinvertebrates were rare (Potužák et al., 2007). These results are comparable to those of Iglesias et al. (2011) who found that small-sized zooplankton were inversely related to fish density in lakes. This ecosystem structure may be explained by the spectrum of the natural food of common carp and the present weed fish. Adult common carp are primarily bottom feeders and prefer macroinvertebrates but they are also water column feeders and consume larger zooplankton (Adámek et al., 2003). High predation pressure by intentionally overstocked fish eliminates large zooplankton individuals and macroinvertebrates at a high rate (Rahman et al., 2006). Weed fish compete with common carp for macroinvertebrates and large zooplankton, especially Daphnia, further reducing zooplankton and macroinvertebrate biomass (Musil et al., 2014). The zooplankton community is thus dominated by small individuals that cannot control the growth of larger and colonial species of phytoplankton (Matsuzaki et al., 2009). The abundance and diversity of macroinvertebrates were further reduced in Dehtár pond by frequent hypoxic conditions above the pond bottom and low biomass of macrophytes (Lemmens et al., 2015). This alteration of the grazing food web structure leads to autochthonous organic matter being accumulated and not being used in the food chain and subsequent fish biomass production, but instead sinking to the pond bottom and being degraded by microbial loop communities (Deines et al., 2015; Přikryl, 1996).

TOC, TN and TP concentrations in the Dehtár pond increased during the study period, mainly due to the accumulation of sestonic (or particulate) organic matter, nitrogen and phosphorus in water. The reason was apparently the increasing phytoplankton biomass as evidenced by the increase of Chla. The increase in the total amount of nutrients during the growing season was obviously due to feed addition rather than to inputs from the surrounding catchment, since the inflow and outflow were negligible. The low water exchange rate and small precipitation observed during this study further supported nutrient accumulation and growth of phytoplankton biomass in the Dehtár pond. These results are consistent with the results of Hopkins et al. (1993), who found that Chla, nutrients and organic matter concentrations were negatively correlated with water exchange and positively correlated with pond production.

$\mathrm{N}-\mathrm{NO}_{3}{ }^{-}, \mathrm{N}_{-} \mathrm{NH}_{4}{ }^{+}$and SRP were low during the whole season. These low concentrations may be explained by denitrification and nutrient uptakes by the growing phytoplankton. Despite the relatively low concentrations of SRP throughout the growing season, phosphorus availability was clearly not a factor limiting the growth of phytoplankton. This is apparent from the molar $C / P$ ratio of seston that varied between 100 and 150 (Fig. 4i), hence not differing much from the Redfield ratio (i.e., 106) in phytoplankton not limited by phosphorus (Hecky and Kilham, 1988; Vrba et al., 1995). There are two plausible explanations of this continuous growth and increase of phytoplankton biomass at such low inorganic nutrient levels: (i) Biotic recycling of organic $\mathrm{P}$ in the water column may explain this sustained growth of phytoplankton (Kamarainen et al., 2009; Knoll et al., 2016). Indeed, the calculated $\mathrm{P}$ needs for the planktonic community were the same as the $\mathrm{P}$ regeneration rate (Tab. 1). In addition, common carp excrete substantial amounts of nutrients that favour phytoplankton growth (Chumchal and Drenner, 2004). (ii) Sediment-bound P could have been released during the study period in the deepest parts of the pond where anoxic conditions were prevailing at the sediment water interface (Sondergaard et al., 2003).

In this study, the Dehtár pond can be classified as slightly autotrophic, based on the calculated metabolic rates. This indicates that the production of organic matter by phytoplankton was higher than its aerobic degradation by various living components of the Dehtár ecosystem. GPP and ER in Dehtár 
were comparable to lakes with similar trophic status (Tab. 3) where production of organic matter by phytoplankton and/or macrophytes was the source of OC that fuelled ER (Laas et al., 2012). On the other hand, GPP and NEP in the Dehtár pond were higher compared to those from heterotrophic lakes with lower trophic status (Tab. 3). In such lakes, various living components of the ecosystem breakdown organic matter by respiration at rates that exceed its production by photosynthesis. This occurs mainly in clear-water, humic and mesotrophic lakes receiving substantial terrestrial organic matter to fuel respiration (Duarte and Prairie, 2005). However, heterotrophy is not always supported by allochthonous OC in lakes. It can also be supported by autochthonous OC accumulated in lake sediment over time. Lake Apopka is an example of a heterotrophic lake in which excess respiration is supported by organic matter originating from a massive burial of macrophytes in the lake sediment. An irreversible ecological disturbance caused by hurricanes switched the community of primary producers from a macrophyte dominated one to a phytoplankton dominated (Bachmann et al., 2000). Despite substantial external OC inputs (feed and manure), the ecosystem metabolism was not heterotrophic in the Dehtár pond. A part of these inputs and GPP were respired while another part was retained in the sediment or metabolised anaerobically by methanogenesis and released into the atmosphere as carbon dioxide $\left(\mathrm{CO}_{2}\right)$ or methane $\left(\mathrm{CH}_{4}\right)$ (Oliveira Junior et al., 2019). Based on the findings of Rutegwa et al. (2019), Dehtář pond may have released 2 tons of diffusive $\mathrm{CH}_{4}-\mathrm{C}$ corresponding to $0.2 \%$ of total $\mathrm{OC}$ inputs to the pond over six months of this study in 2015. Total $\mathrm{CH}_{4}$ emission can be even higher if bubble flux of $\mathrm{CH}_{4}-\mathrm{C}$ is accounted for.

\subsection{Use efficiency of nutrient inputs}

The efficiency of using $\mathrm{OC}, \mathrm{N}$ and $\mathrm{P}$ inputs in the production of fish biomass in the Dehtár pond was $0.9,25$ and $23 \%$ of all OC, TP and TN inputs. The assimilation of OC by fish in this study is comparable to the results of Boyd et al. (2010) who reported the efficiency of OC use in the range of 0.86 to $3.44 \%$ in tilapia ponds. Our value is lower than the OC use efficiency reported by Zhang et al. (2016) who observed higher values, ranging from 4.5 to $8.3 \%$, in polyculture ponds of swimming crab, white shrimp and short necked clam in China. This higher efficiency of OC use apparently resulted from a better use of OC inputs by the reared species exploiting different feeding niches. The efficiency of $\mathrm{N}$ and $\mathrm{P}$ use reported in our study is also in the range of the values reported in other studies of polyculture fishponds. On average, produced fish utilise ca 25 and $20 \%$ of $\mathrm{N}$ and $\mathrm{P}$, respectively, of all $\mathrm{N}$ and $\mathrm{P}$ inputs (Hargreaves, 1998; Rahman et al., 2008).

This comparison shows that in general the efficiency of using $\mathrm{OC}, \mathrm{N}$ and $\mathrm{P}$ inputs is relatively small in the current practice of managing semi-intensive fishponds. A large proportion of inputs (more than $95 \%$ of OC and three quarters of $\mathrm{N}$ and $\mathrm{P}$ ) in this type of ponds is not used by the reared animals. In the Dehtár pond, there are two obvious reasons for this low efficiency: (i) high predation pressure on zooplankton due to high fish biomass, which causes poor transfer of $\mathrm{C}$ from phytoplankton via zooplankton and/or benthic macroinverte- brates to fish; and (ii) low digestibility of the wheat grain used as fish feed. Under such conditions, the fish must be fed by supplementary feed. The low share of zooplankton as a source of food for fish in Czech semi-intensive ponds can be further demonstrated by the fatty acid (FA) composition of the produced common carp. The FA composition in fish muscles reflects the diet (Steffens, 1997). Zooplankton and macroinvertebrates that feed on algae are rich in omega-3 (n-3) and omega-6 (n-6) polyunsaturated fatty acids (PUFA) while cereals are carbohydrate rich and poor in n-3 PUFA (Böhm et al., 2014). The contents of n-3 and n-6 PUFA and the ratio n3/n-6 PUFA are several times lower in carp which feed mostly on cereals in densely stocked ponds than in extensive ponds, where conditions are favourable for large zooplankton (Steffens and Wirth, 2007). Similarly, Mráz et al. (2012) showed that fish produced in semi-intensive Czech fishponds supplemented with cereals have low levels of n-3 and n-6 PUFA and low n-3/n-6 PUFA ratios suggesting the low contribution of zooplankton and macroinvertebrates in their diet and demonstrating low efficiency of using algal primary production in fish biomass production.

The low ability of reared fish to digest cereals is another reason that may explain the low efficiency of using OC, N and P inputs in the Dehtár pond (Degani, 2006; Fagbenro, 1999). The absence of phytase in the carp digestive tract and the presence of digestive enzyme-resistant compounds in cereals (e.g. phytates) is a reason that has been suggested to explain this low cereal digestibility (Fagbenro, 1999). The low digestibility of cereals increases FCR leading to an accumulation of wastes from feed in the fishpond. The FCR in our study was 5.7, which is higher than the average FCR of 4.7 in carp ponds using cereals as supplementary feed (Woynarovich et al., 2011). Thus, partially digested grain promotes primary production by releasing nutrients $(\mathrm{P}$ and $\mathrm{N})$ instead of serving as direct feed for fish. They end up becoming part of the pond bottom and may be ingested again along with plant detritus by carp after being partially degraded by bacteria. Detritus may contribute approximately $70 \%$ of the natural food of common carp in extensively managed ponds (Adámek et al., 2003). However, more research is needed to understand this pathway of nutrient use from feed. The poor quality of supplementary feed used in the Dehtár pond may also be used to explain the contribution of supplied feed to fish production. Fish biomass production in this study $\left(370 \mathrm{~kg} \mathrm{ha}^{-1}\right)$ was lower than the expected production of $565 \mathrm{~kg} \mathrm{ha}^{-1}$, which should be achieved with an average FCR value for carp ponds that use wheat as a supplementary feed (Woynarovich et al., 2011). The FCR of grain is lower than the optimal one that ranges between 1.5 and 2 (Craig et al., 2017).

\section{Conclusion}

The use efficiency of $\mathrm{OC}, \mathrm{TN}$ and TP inputs in the produced fish biomass was low, indicating an overloading of OC, $\mathrm{N}$ and $\mathrm{P}$ in the Dehtár pond, similar to other polyculture carp ponds with comparable fishery management practices. Respiration was the main output of OC from the pond, while accumulation in water and sediment were the main routes for $\mathrm{N}$ and $\mathrm{P}$, respectively. This overloading by inputs impairs pond water quality, and primary production does not contribute 
much to fish production. The main reasons are high fish density and the disruption of the natural food chain in the pond. This also increases the pollution potential of effluents from fish farming activities and emissions of greenhouse gases. Unused inputs represent avoidable production costs. Our results from the Dehtár pond, which were obtained under low flow hydrological conditions when many pond processes were well recognizable, call for more research into pond management practices that will help to improve fish production efficiency while minimizing pollution risks in Dehtár pond and other hypereutrophic carp ponds. These practices include the decrease of fish stock density, stopping the use of manure and replacing cereals by draff or mechanically treated cereals.

\section{Supplementary Material}

Supplementary material provided by the author.

The Supplementary Material is available at https://www.kmaejournal.org/10.1051/kmae $/ 2019043 / \mathrm{olm}$.

Acknowledgements. The study was financially supported by the Ministry of Education, Youth and Sports of the Czech Republic - projects "CENAKVA" (LM2018099), FISHPOND2014 (No. LD14045, programme LD-COST CZ), Grant Agency of the University of South Bohemia (Nos. $122 / 2019 / Z$ and $046 / 2017 / Z$ ), and by the Grant Agency of the Czech Republic (No. 17-09310S). The high frequency monitoring of limnological variables were done in the framework of the FP7 project NETLAKE (EU COST Action ES 1201). The authors are grateful to the fishery company Rybáŕství Hluboká cz. s.r.o, and the Czech Hydrometeorological Institute (České Budějovice branch) for providing fishery production and precipitation data, respectively.

\section{References}

Adámek Z. 2014. Hydrobiology in Fisheries. In: Adámek Z, Helešic J, Maršálek B, Rulík, M. (ed.), Applied Hydrobiology. Vodnany, CZ: USB, 376.

Adámek Z, Sukop I, Rendón PM, Kouřil J. 2003. Food competition between $2+$ tench (Tinca tinca L.), common carp (Cyprinus carpio L.) and bigmouth buffalo (Ictiobus cyprinellus Val.) in pond polyculture. J Appl Ichthyol 19: 165-169.

Adhikari S, Sahu BC, Dey L. 2012. Nutrients budget and effluents characteristics in polyculture of scampi (Macrobrachium rosenbergii) and Indian major carps ponds using organic inputs. Water Sci Technol 66: 1540-1548.

Alongi DM, McKinnon AD, Brinkman R, Trott LA, Undu MC. 2009. The fate of organic matter derived from small-scale fish cage aquaculture in coastal waters of Sulawesi and Sumatra, Indonesia. Aquaculture 295: 60-75.

Bachmann RW, Hoyer MV, Canfield DE. 2000. Internal heterotrophy following the switch from macrophytes to algae in Lake Apopka, Florida. Hydrobiologia 418: 217-227.

Biddanda B, Ogdahl M, Cotner J. 2001. Dominance of bacterial metabolism in oligotrophic relative to eutrophic waters. Limnol Oceanogr 46: 730-739.

Böhm M, Schultz S, Koussoroplis A-M, Kainz MJ. 2014. Tissuespecific fatty acids response to different diets in common carp (Cyprinus carpio L.). PLOS ONE 9: e94759.
Bosma RH, Verdegem MC. 2011. Sustainable aquaculture in ponds: principles, practices and limits. Livestock Sci 139: 58-68.

Boyd CE, Wood CW, Chaney PL, Queiroz JF. 2010. Role of aquaculture pond sediments in sequestration of annual global carbon emissions. Environ Pollut 158: 2537-2540.

Broyer J, Curtet L. 2012. Biodiversity and fish farming intensification in French fishpond systems. Hydrobiologia 694: 205-218.

Čermák B, Cempírková R, Jeroch H, et al. 2008. Krmiva konvenční a ekologická/Feedstuffs conventional and ecological : vědecká monografie. Jihočeská univerzita $\mathrm{v}$ Českých Budějovicích, Zemědělská fakulta, 326 s., České Budějovice.

Chumchal MM, Drenner RW. 2004. Interrelationships between phosphorus loading and common carp in the regulation of phytoplankton biomass. Archiv für Hydrobiol 161: 147-158.

Coloso JJ, Cole JJ, Pace ML. 2011. Difficulty in discerning drivers of lake ecosystem metabolism with high-frequency data. Ecosystems 14: 935.

Craig S, Helfrich LA, Kuhn D, Schwarz MH. 2017. Understanding fish nutrition, feeds, and feeding. Publication 420-256. Yorktown, Virginia: Virginia State University, 4.

Degani G. 2006. Digestible energy in dietary sorghum, wheat bran, and rye in the common carp (Cyprinus carpio L.).

Deines AM, Bunnell DB, Rogers MW, Beard TD Jr., Taylor WW. 2015. A review of the global relationship among freshwater fish, autotrophic activity, and regional climate. Rev Fish Biol Fish 25: 323-336.

del Giorgio PA, Peters RH. 1993. Balance between phytoplankton production and plankton respiration in lakes. Can J Fish Aquatic Sci 50: 282-289.

Duarte CM, Prairie YT. 2005. Prevalence of heterotrophy and atmospheric $\mathrm{CO}_{2}$ emissions from aquatic ecosystems. Ecosystems 8: 862-870.

Fagbenro O. 1999. Apparent digestibility of various cereal grain byproducts in common carp diets. Aquacult Int 7: 277-281.

Florín M, Montes C. 1998. Which are the relevant scales to assess primary production of Mediterranean semiarid salt lakes. Int J Ecol Environ Sci 24: 161-177.

Fránková M, Šumberová K, Potužák J, Vild O. 2017. The role of plant substrate type in shaping the composition and diversity of epiphytic diatom assemblages in a eutrophic reservoir. Fund Appl Limnol/ Arch Hydrobiol 189: 117-135.

George DG, Hurley MA. 2003. Using a continuous function for residence time to quantify the impact of climate change on the dynamics of thermally stratified lakes. $J$ Limnol 21-26.

Hanson PC, Bade DL, Carpenter SR, Kratz TK. 2003. Lake metabolism: Relationships with dissolved organic carbon and phosphorus. Limnol Oceanogr 48: 1112-1119.

Hargreaves JA. 1998. Nitrogen biogeochemistry of aquaculture ponds. Aquaculture 166: 181-212.

Hecky R, Kilham P. 1988. Nutrient limitation of phytoplankton in freshwater and marine environments: a review of recent evidence on the effects of enrichment 1. Limnol Oceanogr 33: 796-822.

Hlaváč D, Másílko J, Hartman P, et al. 2015. Effects of common carp (Cyprinus carpio Linnaeus, 1758) supplementary feeding with modified cereals on pond water quality and nutrient budget. $J$ Appl Ichthyol 31: 30-37.

Hopkins JS, Hamilton RD, Sandier PA, Browdy CL, Stokes AD. 1993. Effect of water exchange rate on production, water quality, effluent characteristics and nitrogen budgets of intensive shrimp ponds. Journal of the World Aquaculture Society 24: 304-320.

Iglesias C, Mazzeo N, Meerhoff M, et al. 2011. High predation is of key importance for dominance of small-bodied zooplankton in 
warm shallow lakes: evidence from lakes, fish exclosures and surface sediments. Hydrobiologia 667: 133-147.

Jeppesen E, Søndergaard M, Sortkjær O, Mortensen E, Kristensen P. 1990. Interactions between phytoplankton, zooplankton and fish in a shallow, hypertrophic lake: a study of phytoplankton collapses in Lake Søbygård, Denmark. Trophic Relationships in Inland Waters. Springer, 149-164.

Kamarainen AM, Penczykowski RM, Van de Bogert MC, Hanson PC, Carpenter SR. 2009. Phosphorus sources and demand during summer in a eutrophic lake. Aquat Sci 71: 214-227.

Knoll LB, Morgan A, Vanni MJ, Leach TH, Williamson TJ, Brentrup JA. 2016. Quantifying pelagic phosphorus regeneration using three methods in lakes of varying productivity. Inland Waters 6: 509-522.

Knud-Hansen CF, Batterson TR, McNabb CD, Harahat IS, Sumantadinata K, Eidman HM. 1991. Nitrogen input, primary productivity and fish yield in fertilized freshwater ponds in Indonesia. Aquaculture 94: 49-63.

Kopáček J, Prochazkova L, Hejzlar J, Blažka P. 1997. Trends and seasonal patterns of bulk deposition of nutrients in the Czech Republic. Atmos Environ 31: 797-808.

Laas A, Noges P, Koiv T, Noges T. 2012. High-frequency metabolism study in a large and shallow temperate lake reveals seasonal switching between net autotrophy and net heterotrophy. Hydrobiologia 694: 57-74.

Lauster GH, Hanson PC, Kratz TK. 2006. Gross primary production and respiration differences among littoral and pelagic habitats in northern Wisconsin lakes. Can J Fish Aquat Sci 63: 1130-1141.

Lemmens P, Mergeay J, Van Wichelen J, De Meester L, Declerck SA. 2015. The impact of conservation management on the community composition of multiple organism groups in eutrophic interconnected man-made ponds. PLOS ONE 10: e0139371.

López-Archilla AI, Molla S, Coleto MC, Guerrero MC, Montes C. 2004. Ecosystem metabolism in a mediterranean shallow lake (Laguna de Santa Olalla, Donana National Park, SW Spain). Wetlands 24: 848-858.

MA. 1998. Decree no 274/1998 on storage and use of fertilisers. In: Agriculture (ed.). Czech Ministry of Agriculture, Prague.

Matsuzaki SS, Usio N, Takamura N, Washitani I. 2009. Contrasting impacts of invasive engineers on freshwater ecosystems: an experiment and meta-analysis. Oecologia 158: 673-686.

Mráz J, Máchová J, Kozák P, Pickova J. 2012. Lipid content and composition in common carp-optimization of n-3 fatty acids in different pond production systems. J Appl Ichthyol 28: 238-244.

Musil J, Adámek Z, Baranyi C. 2007. Seasonal dynamics of fish assemblage in a pond canal. Aquacul Int 15: 217-226.

Musil M, Novotná K, Potužák J, Huda J, Pechar L. 2014. Impact of topmouth gudgeon (Pseudorasbora parva) on production of common carp (Cyprinus carpio)-question of natural food structure. Biologia 69: 1757-1769.

Nhan DK, Milstein A, Verdegem MC, Verreth JA. 2006. Food inputs, water quality and nutrient accumulation in integrated pond systems: a multivariate approach. Aquaculture 261: 160-173.

Oliveira Junior ES, Temmink RJ, Buhler BF, et al. 2019. Benthivorous fish bioturbation reduces methane emissions, but increases total greenhouse gas emissions. Freshw Biol 64: 197-207.

Pálffy K, Présing M, Vörös L. 2013. Diversity patterns of trait-based phytoplankton functional groups in two basins of a large, shallow lake (Lake Balaton, Hungary) with different trophic state. Aquat Ecol 47: 195-210.
Pechar L. 2000. Impacts of long-term changes in fishery management on the trophic level water quality in Czech fish ponds. Fish Manag Ecol 7: 23-31.

Pokorný J, Hauser V. 2002. The restoration of fish ponds in agricultural landscapes. Ecol Eng 18: 555-574.

Pokorný J, Pechar L. 2000. Development of fishpond ecosystems in the Czech Republic. Role of management and nutrient input (Limnological review). Sylvia 36: 8-15.

Pokorný J, Prikryl J, Faina R, et al. 2005. Will fish pond management principles from the temperate zone work in tropical fish ponds. Nat Construc Wetlands 382-399.

Potužák J, Duras J, Drozd B. 2016. Mass balance of fishponds: are they sources or sinks of phosphorus? Aquacult Int 24: 1725-1745.

Potužák J, Huda J, Pechar L. 2007. Changes in fish production effectivity in eutrophic fishponds-impact of zooplankton structure. Aquacult Int 15: 201-210.

Přikryl I. 1996. Development of fishery management in ponds and its reflection in zooplankton structure as a possible criterion of pond's biological value in the Czech Republic. In: Flajšhans, M. (ed.), Collection of scientific work to 75th anniversary of establishment of Research Institute of Fish Culture and Hydrobiology. Vodnany, CZ: USB, 153-166.

Rachon L, Szumilo G, Brodowska M, Wozniak A. 2015. Nutritional value and mineral composition of grain of selected wheat species depending on the intensity of a production technology. J Elementol 20.

Rahman M, Verdegem M, Nagelkerke L, Wahab M, Milstein A, Verreth J. 2006. Growth, production and food preference of rohu Labeo rohita (H.) in monoculture and in polyculture with common carp Cyprinus carpio (L.) under fed and non-fed ponds. Aquaculture 257: 359-372.

Rahman MM, Nagelkerke LA, Verdegem MC, Wahab MA, Verreth JA. 2008. Relationships among water quality, food resources, fish diet and fish growth in polyculture ponds: a multivariate approach. Aquaculture 275: 108-115.

Reynolds C, Davies P. 2001. Sources and bioavailability of phosphorus fractions in freshwaters: a British perspective. Biolog Rev 76: 27-64.

Rothschein J. 1983. Kolobeh fosforu a ryp vo vodárenských nádřziach. Vodni hosp B33: 9-13.

Rutegwa M, Gebauer R, Veselý L, et al. 2019. Diffusive methane emissions from temperate semi-intensive carp ponds. Aquacult Environ Interact 11: 19-30.

Sadro S, Melack JM, MacIntyre S. 2011. Depth-integrated estimates of ecosystem metabolism in a high-elevation lake (Emerald Lake, Sierra Nevada, California). Limnol Oceanogr 56: 1764-1780.

Scheffer M, Carpenter S, Foley JA, Folke, C, Walkerk B. 2001. Catastrophic shifts in ecosystems. Nature 431: 591-596.

Schindler DW, Hecky R, Findlay D, et al. 2008. Eutrophication of lakes cannot be controlled by reducing nitrogen input: results of a 37-year whole-ecosystem experiment. Proc Natl Acad Sci 105: $11254-11258$.

Sommer U, Adrian R, De Senerpont Domis L, et al. 2012. Beyond the Plankton Ecology Group (PEG) model: mechanisms driving plankton succession. Annu Rev Ecol Evol Syst 43: 429-448.

Sondergaard M, Jensen JP, Jeppesen E. 2003. Role of sediment and internal loading of phosphorus in shallow lakes. Hydrobiologia 506: 135-145.

Staehr PA, Bade D, Van de Bogert MC, et al. 2010. Lake metabolism and the diel oxygen technique: State of the science. Limnol Oceanogr Methods 8: 628-644. 
Staehr PA, Sand-Jensen K. 2007. Temporal dynamics and regulation of lake metabolism. Limnol Oceanogr 52: 108-120.

Steffens W. 1997. Effects of variation in essential fatty acids in fish feeds on nutritive value of freshwater fish for humans. Aquaculture 151: 97-119.

Steffens W, Wirth M. 2007. Influence of nutrition on the lipid quality of pond fish: common carp (Cyprinus carpio) and tench (Tinca tinca). Aquac Int 15: 313-319.

Svobodova Z, Lloyd R, Baddow L, Essex C, Machova J, Vykusova B. 1993. Water quality and fish health. EIFAC Technical paper 54 59.

Tsai J-W, Kratz TK, Hanson PC, et al. 2008. Seasonal dynamics, typhoons and the regulation of lake metabolism in a subtropical humic lake. Freshw Biol 53: 1929-1941.

Vollenweider RA, Kerekes JJ. 1982. Eutrophication of waters. Monitoring assessment and control. Environment Directorate OECD, Paris. 154 p
Vrba J, Vyhnálek V, Hejzlar J, Nedoma J. 1995. Comparison of phosphorus deficiency indices during a spring phytoplankton bloom in a eutrophic reservoir. Freshw Biol 33: 73-81.

Wetzel RG. 2001. Limnology: Lake and River Ecosystems, 3rd edn. ed. Elsevier, San Diego: Academic Press.

Wezel A, Robin J, Guerin M, Arthaud F, Vallod D. 2013. Management effects on water quality, sediments and fish production in extensive fish ponds in the Dombes region, France. Limnologica 43: 210 218.

Woynarovich A, Bueno PB, Altan O, et al. 2011. Better management practices for carp production in Central and Eastern Europe, the Caucasus and Central Asia. FAO, Rome: FAO Fisheries and Aquaculture Technical Paper.

Zhang K, Tian X-1, Dong S-1, Feng J, He R-p. 2016. An experimental study on the budget of organic carbon in polyculture systems of swimming crab with white shrimp and short-necked clam. Aquaculture 451: 58-64.

Cite this article as: Rutegwa M, Potužák J, Hejzlar J, Drozd B. 2019. Carbon metabolism and nutrient balance in a hypereutrophic semiintensive fishpond. Knowl. Manag. Aquat. Ecosyst., 420, 49. 